УДК 001; 004.7

Буров Олександр Юрійович

доктор технічних наук

Інститут інформаційних технологій і засобів навчання НАПН України, м. Київ, Україна

burov@ipnet.kiev.ua

\title{
ТЕХНОЛОГІЇ ТА ІННОВАЦІЇ В ДІЯЛЬНОСТІ ЛЮДИНИ ЕРИ ІНФОРМАЦЇ̈: ЛЮДИНА ТА ІКТ
}

\begin{abstract}
Анотація. Наводиться короткий огляд проектів, розпочатих Національним фондом науки США, які стосуються нових знань щодо інтеграції і спільного розвитку соціальних і технічних систем, мають потенціал для трансформування освіти/досліджень, покращення якості життя й економічного процвітання, а також повинні забезпечити випереджальний розвиток інформаційно-комунікативних технологій для всіх сфер діяльності людини: антропоцентрична комп'ютеризація, інтеграція інформації та інформатика, робастний інтелект, системи людина - кіберпростір, а також у двох перехресних технічних галузях взаємодія людей та/або роботів, безпека і захист інформації.
\end{abstract}

Ключові слова: інформаційно-комунікаційні технології; інтелектуальні мережі.

\section{1. ВСТУП}

Науково-технічний прогрес і розвиток технологій, зокрема [1], призвели до зростання ролі інновацій у всіх сферах діяльності [2], виникнення в останні десятиліття і суттєвої зміни останнім часом ролі інформаційно-комунікативних технологій (IКТ) у житті людини, способів і форм іiі діяльності [3]. Глобальний характер цих тенденцій виводить на перше місце серед пріоритетів людства на початку XXI ст. потребу в розвитку людського капіталу [4], на відміну від усієї попередньої історії, коли домінували інтереси отримання засобів фізичного життя, виробництва та фінансово-економічних засобів забезпечення попередніх двох.

Постановка проблеми. Враховуючи, що нинішне суспільство живе в інформаційну еру [5], перестає бути дивним, що цифровий простір дедалі ширше охоплює всі сфери нашого життя i, насамперед, освітню як систему підготовки i формування інтелектуального капіталу [6]. Наразі значна увага приділяється якості навчання [7], дистанційним і мережним засобам [8; 9]. Проте ергономічні особливості людини, яка взаємодіє з ІКТ, на часі ще не стали складником загальної системи якості освіти [10] через недостатнє загальне розуміння особливостей мережних технологій як засобу і середовища діяльності людини [11].

Аналіз останніх досліджень і публікацій. Очевидно, що складність і мінливість $\epsilon$ двома визначними рисами Ери інформації [3], що продовжує ставити завдання такого типу [12]. Насамперед, це стосується нових технологій, які супроводжують нас у всіх сферах нашого життя і діяльності - інформаційно-комунікативних технологій, а також безпосередньо впливають не тільки на наше сьогодення, але й на майбутнє $[13 ; 14]$.

Мета статті - аналіз глобальних тенденцій взаємної адаптації людини й інформаційно-комунікативних технологій у цифровому світі, особливості цієї адаптації у сфері освіти.

\section{2. МЕТОДИ ДОСЛІДЖЕННЯ}

Дослідження проводилось 3 метою узагальнення результатів науково-дослідних робіт автора в Україні і в міжнародних експертних групах. Під час дослідження 
використовувались такі методи: аналіз загальних тенденцій розвитку технологій, аналіз теоретичних джерел із проблем інтелектуальних мереж, вивчення й узагальнення сучасних знань щодо проектування і застосування інформаційних мережних технологій для завдань науки, управління та освіти.

\section{3. РЕЗУЛЬТАТИ ДОСЛІДЖЕННЯ}

Загальновизнаним $є$ факт розвитку інформаційно-комунікативних і соціальних мереж у сучасному житті людини в різних сферах: освітній, професійній, повсякденного спілкування, побуту і рекреаційній. Швидкість їх утворення, розвитку та трансформації $є$ незрівнянно вищими відносно інновацій навіть минулого століття. Проте попри загальне враження щодо їх хаотичності й непередбачуваності можливо виділити певні перспективи і тенденції розвитку мереж, оскільки їх проектування і розроблення не є миттєвим актом, а наслідки застосування мають значний вплив на глобальні тенденції становлення загальнолюдської цивілізації.

Слід зазначити, що серед існуючих і таких, що проектуються, мереж усе більшого значення набувають інтелектуальні мережі для використання у різних сферах. Найбільш фундаментально підготовленим підходом є програма створення таких мереж, запропонована Національним фондом науки США «Інформаційні та інтелектуальні системи: просування антропоцентричної комп'ютеризації, інтеграція інформації та інформатика, робастний інтелект», що передбачає всебічне дослідження і розвиток різних аспектів майбутніх інтелектуальних мереж 3 наданням адекватного фінансування організаціям-учасникам проекту [15].

Напрям інформаційних та інтелектуальних систем (IIS) підтримує наукові i прикладні дослідження, а також освітні проекти, що:

- стосуються нових знань щодо інтеграції і спільного розвитку соціальних i технічних систем, особливо тих, що мають потенціал трансформування освіти i досліджень, покращення якості життя й економічного процвітання для населення;

- можуть підвищити можливості людини і техніки створювати, робити відкриття та користуватися знаннями шляхом удосконалення здатностей представляти, збирати, зберігати, організовувати, візуалізувати та спілкуватися щодо даних та інформації;

- можуть підвищити рівень розвитку інформаційних технологій в науці і техніці;

- можуть підвищити рівень знань щодо того, як комп'ютерні системи можуть працювати автономно, правильно та гнучко.

У програмі планувалось фінансування наукових i прикладних досліджень й освітніх проектів у 3-х головних технічних галузях:

- антропоцентрична комп'ютеризація (НCC);

- інтеграція інформації та інформатика (III);

- робастний інтелект (RI)

- й у 2-х перехресних технічних галузях:

- взаємодія людей та/або роботів (HRI);

- безпека і захист інформації (IPS).

Проте швидкі зміни в реальному житті внесли корективи i в остаточному розподілі тем Програми замість галузі IPS виділено нову галузь - Cyber-Human Systems (CHS), - «системи людина - «кіберпростір», що підтверджує прогноз сучасних тенденцій у зміні технологій [16].

Слід відзначити, що спеціальна увага у Програмі приділяється розробці навчального матеріалу (IISCD), що може сприяти вдосконаленню вищої освіти у 
вищезазначених основних і перехресних галузях. Проекти мають поширити нові знання і підготувати наступні покоління професіоналів у сферах досліджень й освіти.

Заохочується креативне мислення - будуть підтримуватися високо ризикові проекти 3 високим потенціалом, цікаві нові дослідження 3 потенціалом досягнення значних результатів. Попри це, заохочуються міждисциплінарні i міжнародні переговори й обмін знаннями.

У цілому для виконання програми були відібрані 1192 проекти, термін виконання більшості яких закінчується у 2014-2016 рр.

Проекти у напрямі антропоцентричної комп'ютеризації (НCC) охоплюють широкий спектр питань у сфері комп'ютерної науки та інформаційних технологій, що поєднує спільна риса: людина (особа, команда, організація, спільнота) бере безпосередню участь і є невід'ємною частиною всіх стадій розвитку інформаційних технологій і їх використання; люди розробляють нові технології; люди окремо, у групах або організаціях користуються ними; люди очікують і насолоджуються їхніми перевагами; вони дізнаються про переваги такого використання (не важливо, очікувані вони чи ні) та трансформують ці знання у наступне покоління систем. У той же час нові інформаційні технології і людські спільноти еволюціонують і поєднуються, залучаючи один одного до процесу. Як результат, проект інформаційних технологій повинен втілювати цінності й вимоги людини.

Слід зауважити, що у галузі антропоцентричної комп’ютеризації підтримуються проекти, що вивчають використання інформаційних технологій у високорозподіленому і швидкозмінному середовищі на різних рівнях, що мають найближчі або віддалені цілі. Насамперед підтримуються сміливі підходи до вдосконалення системи освіти, наприклад, через інтеграцію досліджень й освіти в об'єднані інтернаціональні комп'ютерні наукові мережі (колаборації), що вимагають застосування нових методів для надання користувачу можливості отримання реального досвіду створення науки i можливості працювати разом з іншими студентами, викладачами, науковцями 3 різних країн. Передбачається, що антропоцентричні технології дадуть людині змогу користуватися перевагами комп'ютерної техніки, нададуть можливість людям 3 обмеженими фізичними здібностями, молоді, літнім людям та членам груп, представлених у недостатній кількості, брати повноцінну участь в інформаційній спільноті, а також будуть сприяти незалежності кожного виконавця на фоні соціальних стосунків та автономії.

Прийняті до виконання проекти, окрім того, мають поглиблювати розуміння глобалізації комунікаційних процесів і комерції, глобальних ланцюжків створювання цінностей, аутсорсингу в усіх формах, трансформації і генерації баз знань, а також ролі інформаційних технологій в інноваціях і конкуренції. Заохочуються дослідження онлайн-взаємодій, що виходять за межі географічних або культурних меж завдяки новим програмам, орієнтованим на людей і їх спілкування, таким, як:

- Інтернет-голосування та інші електронні форми виявлення громадської позиції,

- спільні електронні публікації,

- блоги,

- онлайн-ігри з участю декількох гравців,

- мистецькі і культурні програми,

- віртуальний театр,

- спільне створення музики на відстані.

Попри це, заохочуються дослідження впливу інформаційних технологій у стосунках влади і громадян, цифрової демократії і проекти створення і розвитку ITспільнот. 
Планується, що дослідження у галузі антропоцентричної комп’ютеризації будуть спрямовані на безпрецедентні відносини «людина - комп’ютер» і «людина - людина» через систему свого соціального оточення, системи, що розуміють поняття відстані людською мовою, реалістичні імерсивні (занурювальні) і мульти-сенсорні технології, а також пряму взаємодію мозку й комп'ютера. Антропоцентричне дослідження трансформує стосунки людини і комп'ютера так, що комп'ютер більше не буде розвагою або, що ще гірше, перешкодою, а стане робочим інструментом, засобом навчання, користування вдома й у грі, а також буде сприяти природній і продуктивній взаємодії між людиною і засобами програмного забезпечення. Такі розробки покращать людські здібності і креативність людини через високоінтерактивні візуальні інтерфейси, обладнані інструментами і засобами, що дають змогу людині синтезувати певну інформацію, виокремлювати іiі серед великої кількості динамічної і часто суперечливої інформації, знаходити те, що очікувалось, і винаходити неочікуване. Антропоцентрична комп'ютеризація буде заохочувати дослідження щодо того, як людина, у різних ролях і середовищах, отримує комп'ютерні артефакти і використовує ïx.

Перелік питань, що входять до сфери антропоцентричної комп'ютеризації, включають, але не обмежуються:

- розв'язання проблем у розподілених середовищах, що відносяться до інформаційних Інтернет-систем, сіток, сенсорних інформаційних мереж, мобільних і переносних інформаційних продуктів;

- мультимедійні й мультимодальні інтерфейси, що поєднують мову, текст, графіку, жести, рухи, дотики, звуки тощо, що використовуються людьми й машинами для спілкування один з одним;

- інтелектуальні інтерфейси і моделювання користувача, візуалізація інформації, адаптація інформації під різні можливості дисплеїв, модальність, пропускну спроможність та час очікування;

- багатоагентні системи, що контролюють i координують дії i розв'язують комплексні проблеми у розподілених середовищах у різних сферах діяльності, наприклад, ліквідації надзвичайних ситуацій, електронній комерції, освіті, забезпеченні благополучної старості;

- моделі ефективної взаємодії між людьми через комп’ютери під впливом багатьох обмежуючих факторів (наприклад, відеоконференція, спілкування в умовах високої/низької пропускної спроможності мережі тощо);

- визначення семантичних структур для мультимедійної інформації для підтримки кросс-модального введення і виведення;

- спеціальні рішення особливих потреб певних спільнот;

- спільні системи, що сприяють наукоємній і динамічній взаємодії між інноваціями і генерації знань крізь організаційні, національні та професійні межі;

- новітні методи підтримки і покращення соціальної взаємодії, включаючи інноваційні ідеї, такі, як техніка застосування ортопедичних апаратів, емоційна обробка даних, здобуття досвіду;

- дослідження того, як соціальні організації, такі, як урядові заклади, корпорації відповідають і підтримують нові інформаційні технології, особливо ті, що мають на меті вдосконалення наукового розуміння і технічного дизайну.

Очікується, що антропоцентрична комп'ютеризація підтримає вчених у галузі комп'ютерних технологій і соціології, дослідників, які вивчають проблеми поведінки, а також економістів, чиї дослідження пов'язані з плануванням і розумінням НСС. Однак, перевага надається насамперед комп'ютерним та інформаційним наукам, а вже потім соціальним, поведінковим та економічним. Алгоритми, протоколи та апаратне 
забезпечення для створення мобільних мереж не розглядаються, якщо тільки головний акцент не зроблено на індивідуальному або груповому користуванні.

У рамках цього напряму профінансовано 133 проекти, як, наприклад:

- принципи проектування інформаційних мереж, що підтримують соціальне виробництво знань [13; 14],

- широкомасштабні людиноцентричні системи координації для підтримки незалежних задач у контексті,

- до більш природних та інтерактивних інтерфейсів «мозок - комп'ютер».

Загальною рисою напряму є орієнтація на більше урахування психофізіологічних можливостей людини для оцінювання ефективності розумової діяльності, що прогнозувалося і пропонувалося різними авторами раніше $[16 ; 17 ; 19 ; 20]$.

Напрям інтеграція інформації та інформатика (III) передбачає, що цифровий контент має різні стадії розвитку і зрілості, може відповідати різноманітним потребам і завданням. У такому контексті ієрархія покращення і структури йде від даних до інформації, від інформації до знань, від знань до розуміння, i, нарешті - до рішення, дії або нових засобів, що підтримуються відповідними цифровими технологіями. Прогрес в інформаційному полі - це перехід від біту до структури даних, далі до контекстуалізованого інформаційного об'єкта і ресурсів, що сприяють створенню і користуванню знаннями й розумінню через людське мислення та штучний інтелект. Предметом дослідження $є$ цифровий контент і релевантні процеси, технології та участь людини у створенні, зберіганні, запиті, представленні, організації, інтеграції, оновленні, управлінні, аналізі, безпеці, конфіденційності та взаємодії на кожній стадії ієрархії технологічного середовища від персонального комп'ютера до глобально розподілених динамічних мережних депонованих систем.

Підтримуються такі напрями діяльності: 1) базове дослідження інтеграції інформації та інформатики (III-COR), що доповнює результати досліджень інтеграції інформації й інформатики та освіти, і посилює їхній вплив і значення в усіх сферах діяльності; 2) контекстуальне дослідження (III-CXT), що винаходить і розширює потенціал дослідження інтеграції інформації та інформатики в певному контексті.

Слід зазначити, що контекст розуміється у найширшому сенсі й означає природне i створене людиною середовище (сфера діяльності), у якому основою $\epsilon$ взаємозалежності і взаємовідносини. Метою контекстуального дослідження (III-CXT) є: 1) величезний вплив на сферу діяльності, де робляться покращення; 2) висвітлення недоліків і встановлення нових пріоритетів для досліджень у питаннях III-COR aбо IIICXT.

Отже, у контекстуальному дослідженні інтеграції інформації та інформатики, комп'ютер, інформаційні науковці та інженери мають співпрацювати з учасниками середовища. Учасниками середовища можуть бути вчені й інженери у цій галузі; федеральні, державні, місцеві урядові заклади; гуманітарні факультети; клініки, госпіталі; неурядові організації. Такі вимоги роблять можливим встановлення контексту, виділення цікавих наукових проблем у сфері комп'ютеризації і забезпечення середовища відповідним підтвердженням запропонованих рішень. Усі проекти містять опис дослідження в контекстуальному середовищі i мають демонструвати, що співпраця є незалежною і реальною. Обов'язковими питаннями, що вирішуються у проектах, є такі: що таке інноваційна комп’ютерна наука, комп'ютерна техніка, який внесок до інформаційної науки робить це дослідження? Нові знання повинні бути загальними для різних середовищ.

Питання, що входять до галузі інтеграції інформації та інформатики, охоплюють, але не обмежуються такими:

- трансформація первинних даних в інформацію і знання; 
- створення нових форм цифрового контенту, представлення цифрового контенту, доступ до об’єктних структур, послуги надання, презентації та засоби аналізу;

- довгострокове зберігання й архівування цінних інформаційних ресурсів;

- моделі інформаційних структур у прикладних сферах, що будуються на неповних даних, наприклад, для відтворення минулих подій, культур, об'єктів та місць у галузі археології, історії, палеонтології, геології та екології;

- зберігання, організація, відтворення, оновлення та відкриття даних, тексту, мови, мультимедія, багатомірних структур та потоків;

- здобуття структурованої інформації з неструктурованих джерел;

- винайдення, синтез, анотування та візуалізація інформації і знань;

- алгоритми персоналізації, організації, навігації, пошуку, інтерпретації та презентації інформації різних типів різними методами;

- дизайн, організація, управління інформаційними інфраструктурами, включаючи інформаційний потік, адаптивну еволюцію і можливість взаємодії;

- середовище користування знаннями для науки і техніки;

- дослідження інформаційної інтеграції, що веде до єдиного інтерфейсу безлічі неоднорідних незалежно розвинених інформаційних джерел;

- візуалізація інформації і візуальна аналітика;

- дослідження інформаційної інтеграції в питаннях, пов'язаних 3 ліквідацією стихійних лих, а саме пошкоджень засобів телекомунікації, проблем у передаванні повідомлень і втраті даних.

Напрям інтеграції інформації та інформатики є продовженням робіт за тематикою цифровий уряд; цифрові бібліотеки та архіви; управління інформацією, даними та знаннями; інтеграція наукової і прикладної інформації та інформатики [17].

Приклад проектів, що фінансуються:

- проектування й аналіз експериментів щодо мережної популяції;

- структуровані і розвивальні дані цитування;

- каузальні бази даних.

Напрям робастного інтелекту (RI) охоплює обчислювальний інтелект i моделювання багатьох людських і тваринних здібностей, що демонструють інтелект і адаптивність у неструктурованих і нестабільних середовищах [18]. Основні цілі цієї технічної галузі охоплюють навчання, теорію, проектування та застосування загального, інтегрованого, інтелектуального сприйняття, комунікації й обгрунтування можливостей, що не обмежені однією конкретною проблемою в одному конкретному контексті. Системи, що демонструють функціональний інтелект, можуть використовувати множину підходів до моделювання й обгрунтування, таких, як висновки за аналогією, статистичні й логічні висновки; мати справу з неостаточними i змінними поняттями й середовищами та інтегрувати можливі неоднорідні знання й методології аргументації додатковими шляхами. Подібні системи здатні інтелектуально реагувати на незвичні ситуації, недостатність, конфлікти та неясність у їхніх даних, знаннях і можливостях 3 рівнем гнучкості, що може порівнюватися 3 людиною й твариною $[19,20]$. Робастні інтелектуальні системи мають автономний доступ до свого середовища, будують плани для досягнення загальних цілей, виносять уроки зі свого досвіду й діляться своїми знаннями, висновками та аргументацією з іншими, так, що вони можуть розвивати свої можливості і робастність.

Робастні інтелектуальні системи можуть функціонувати на різних рівнях i синергетично інтегрувати нервові, перцептивні, розумові та комунікаційні аспекти інтелекту. Щодо моделювання унікальної здатності людини спілкуватися рідною мовою, робастні інтелектуальні системи намагаються досягти рівня людини у розумінні 
і спілкуванні мовою, швидкій інтерпретації й анотуванні інформації, а також перекладі різними мовами. Вони повинні досягти стабільності й високого рівня виконання у візуальних і моторних системах людей і тварин. Роботизовані системи, що мають робастний інтелект, здатні інтегрувати мультимодальну сенсорну інформацію, навчатися та робити висновки 3 попереднього досвіду 3 метою автономного функціонування у групах, або взаємодії 3 людиною в динамічних і нестабільних середовищах. Робастні інтелектуальні системи можуть використовувати обчислювальні стратегії, що застосовуються людиною або твариною. В усіх своїх аспектах, робастні інтелектуальні системи здатні використовувати свій попередній досвід для розв'язання нових проблем і функціонування у нових середовищах; вони можуть не лише покращувати речі, з якими стикалися, але також, що, мабуть, навіть більш важливе, здатні передбачати і пропонувати нові завдання.

Напрям робастного інтелекту охоплює, але не обмежується, такими питаннями:

- схеми розв'язання проблем, що інтегрують розумові, моторні, перцептивні, мовні можливості та здатність навчатися з досвіду;

- гібридні структури, що інтегрують і поєднують різні методи, такі, як дедуктивне, імовірнісне, аналогічне, доказове, аналітичне або субаналітичне мислення.

- комп'ютерні моделі людського пізнання, сприйняття та комунікації для загальних або спеціалізованих середовищ і завдань, охоплюючи отримання і репрезентацію знань;

- новітні підходи до вже окреслених проблем у машинному розпізнаванні образів, наприклад, визначення і моделювання контурів, форми, області, об'єктів, людей, сцен, подій, діяльності у зображеннях формату 2D або 3D, або відео у форматі 3D;

- системи машинного розпізнавання об'єктів, що знаходять біологічні компоненти i можливості;

- синергетичне і спільне дослідження інноваційних і новітніх технологій з метою покращення інтелекту, мобільності, автономності, управління, адаптивності та інтерактивності роботизованих систем, що функціонують у неструктурованих i нестабільних середовищах;

- дослідження інтелектуальної i допоміжної робототехніки, пристроїв для застосування у неврології, функціонування та взаємодії декількох автоматичних пристроїв, мікро- і наноробототехніки з урахуванням новітніх підходів до надання відчуттів, сприйняття, пізнавальних здатностей, уведення в дію, автономного управління, навчання та адаптації, мультимодальної взаємодії між людиною і роботом [19];

- комп'ютеризовані підходи і схеми аналізування, розуміння, генерації та підсумовування мовлення, тексту та інших форм комунікації (наприклад, жестів); взаємодія різних форм комунікації; діалог, спілкування та інші менш формальні жанри (наприклад, протокол переговорів);

- комп'ютеризовані моделі значення, наміру та реалізації на різних рівнях мовного відображення з приділенням особливої уваги семантиці і прагматиці; когнітивні й нейролінгвістичні підходи до модельного оцінювання;

- новітні підходи до давнішніх проблем з обробки мови, наприклад, розпізнання мови, машинний переклад, якісні параметри, багатомовна комунікація людини 3 машиною, включаючи інтелектуальне представлення інформації;

- комп'ютеризовані підходи до обробки мови для недостатньо представлених (малочисельних) груп, таких, як групи мов етнічної меншості, групи інвалідів;

- функціональне моделювання, теорія та аналіз комп'ютеризованих, репрезентативних, кодованих стратегій нервових систем; 
- засновані на неврології комп'ютеризовані підходи до комп'ютерного зору, робототехніки, комунікації та мислення, а також системи, що поєднують їх $\mathrm{i}$ втілюють емпірично виведені стратегії.

Напрям робастного інтелекту підтримує проекти, які вдосконалять межі дисциплін, таких, як комп’ютеризована неврологія, мова, зір, робототехніка, штучний інтелект, а також ті, що інтегрують різні аспекти цих дисциплін. I хоча від кожного проекту не вимагається розробляти повне інтегроване рішення, проекти, що фокусуються на вдосконаленні певного аспекту, повинні мати більш загальну мету, ніж зазначена вище.

Роботи за цим напрямом $є$ продовженням досліджень 3 таких питань як: штучний інтелект і когнітивні системи; комп'ютеризована неврологія; машинний зір; людська мова і комунікація; робототехніка.

Прикладом прийнятих до фінансування проектів можуть бути:

- роботизований пошук змінних об' єктів,

- планування і навчання з макродій у кооперативних мультиагентних системах,

- поєднання семантичного аналізу й аналізу соціальних мереж.

\section{Перехресні технічні галузі}

Розглядаються заявки на дослідження у двох нижчезазначених перехресних технічних галузях. Очікується, що координатори програми Відділення будуть брати участь у розгляді заявок перехресних дисциплін.

Взаємодія людей та/або роботів (HRI) фокусується на фізичній, когнітивній та соціальній взаємодії між людьми та/або роботами з метою проектування й розширення людських можливостей та забезпечення спільного інтелекту. Для кращого розуміння структурної складності такої взаємодії, у процесі проектування роботів (або пристроїв), що будуть корисними для людини у багатьох сферах діяльності (наприклад, допомога у критичних ситуаціях; літнім людям; медична допомога; підвищення продуктивності робочого місця тощо) необхідні нові знання.

Безпека $\boldsymbol{i}$ захист інформації (IPS) фокусується на методах оцінювання, захисту та конфіденційності у комп'ютерних соціальних системах, де люди діляться інформацією про себе, особливо в динамічних і мобільних ситуаціях. Відділення інформаційних та інтелектуальних систем підтримує вивчення стратегій і технологій, що дозволяють співробітництво між організаціями, i вивчення захисту конфіденційності так, щоб можна було робити висновки 3 даних, але при цьому зберігалася конфіденційність, а також практичність таких систем. Дослідження повинні виявити нові уявлення про приватність, наприклад, в онлайн-середовищі. Заявки можуть стосуватися алгоритмів безпеки, механізмів, схем або проведення емпіричних досліджень, наприклад, людські відчуття після втрати конфіденційності, або випадки крадіжки персональних даних. Не розглядають проекти, що стосуються алгоритмів шифрування і протоколів аутентифікації.

Одночасно варто зазначити не тільки теоретичний, але й практичний розвиток $\mathrm{i}$ створення інтелектуальних мереж, насамперед, у Японії, а також досвід їх створення і функціонування, розглянутий на семінарі «Людиноцентричні системи: інформація, взаємодія та інтелект».

Новий напрям системи людина - кіберпростір (CHS) швидко розвивається і часто визначається як передовий рубіж досліджень, що підтримуються Програмою. CHS розвинувся 3 наступних попередніх програм: людино центричні системи, інтерфейс людина - комп'ютер, універсальний доступ, цифрове суспільство та технології, до певної міри - електронний уряд, авторське право в інформаційній сфері, взаємодія людей та/або роботів. Виходячи 3 цього, можна зрозуміти тенденції виникнення напряму CHS як проекти у тривимірному просторі людина - комп'ютер - 
середовище, тобто реалізацію проблематики ергономіки/людського чинника згідно до поглядів українських учених [16]. Розмірність «людина» відповідає дослідженням, що підтримують, розширюють можливості і відповідають потребам індивідууму через командну діяльність як співпадіння ціле-орієнтованих груп через суспільство і як неструктурований підбір зв'язаних людей (рис. 1). Комп'ютерна розмірність виростає від фіксованого набору комп'ютерних пристроїв, до яких людина має доступ, мобільних пристроїв, що супроводжують людину всюди, до обчислювальних систем сенсорів i аудіо-візуальних пристроїв, які складають оточуюче середовище. Середовищна розмірність утворюється 3 дискретних фізичних обчислювальних пристроїв, систем змішаної реальності й імерсивних віртуальних середовищ. Ця тривимірна характеристика CHS призначена надихнути, а не обмежити майбутні дослідження.

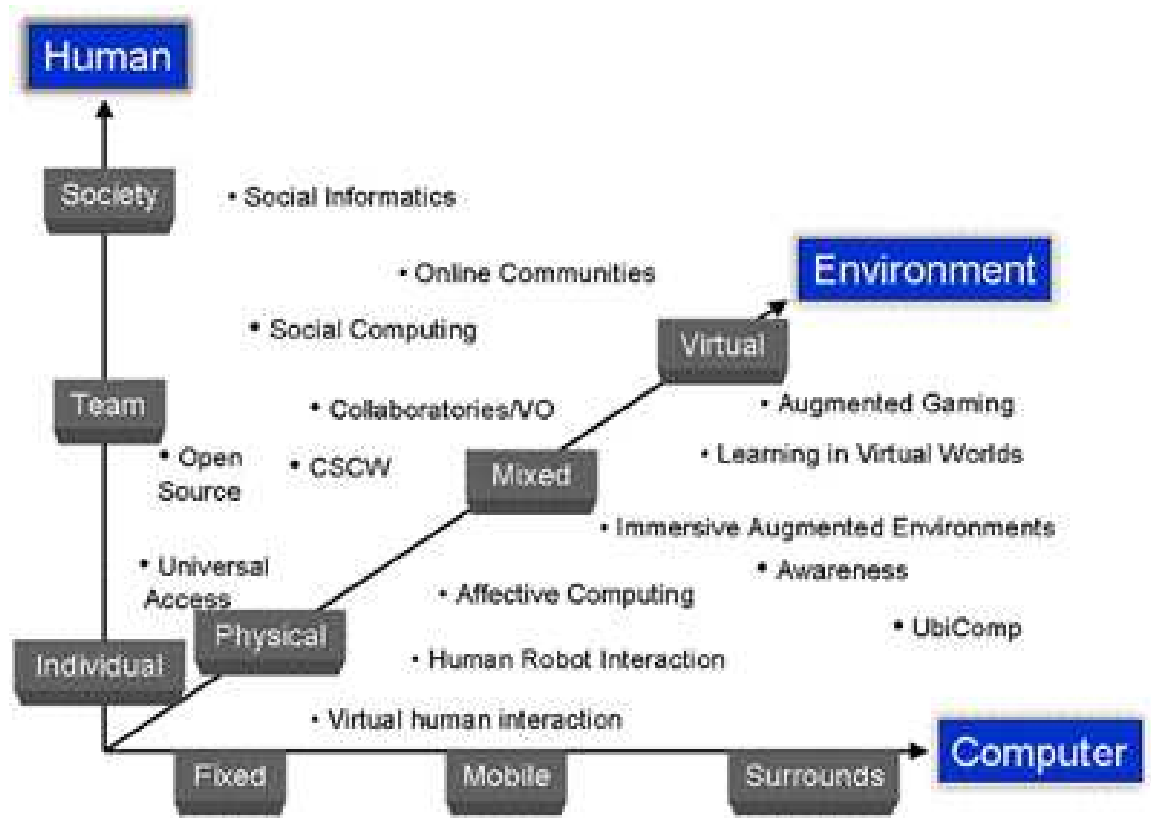

Рис. 1. 3D структура напряму «системи людина - кіберпростір» (наводиться за [21])

Прикладами проектів цього напряму можуть слугувати:

- соціальне навчання у змішаних людино-робототехнічних групах для людей 3 вадами розвитку,

- використання роботів як посередників для збору сенситивної інформації від дітей,

- до прозорості персоналізації у Web,

- як рекомендації і пояснення впливають на преференції в соціальних мережах.

Слід зазначити, що наведені сучасні освітні тренди розробок у різних напрямах систем людина - IКТ актуалізують наукові дослідження з питань розвитку Інтернет орієнтованих форм навчання і виховання школярів. Модернізація і розвиток освіти повинні набути випереджального безперервного характеру, гнучко реагувати на всі процеси, що відбуваються в Україні і світі, враховувати глобальні освітні тенденції і перспективні розробки, які найближчим часом можуть стати повсякденним інструментарієм навчання. Широке використання запланованих розробок збагатить ресурси електронних соціальних мереж, які $\epsilon$ автоматизованим соціальним середовищем, що дозволяє спілкуватися групі користувачів, об'єднаних спільними 
інтересами, швидко обмінюватися новим освітнім інструментарієм і даними, збагатити форми індивідуального і групового навчання.

Створення широкого спектру нових засобів підтримки мереж, у т. ч. соціальних, підвищує актуальність проблеми теоретичного дослідження суттєвих цільових i змістово-технологічних (методичних) аспектів навчально-виховного процесу, який повинен здійснюватись в інформаційно-освітньому середовищі учнів (його статику i динаміку, у тому числі передбачити і врахувати розвиток будови інформаційних освітніх систем, вплив і особливості взаємозв'язків їх складників 3 елементами оточуючого середовища залежно від ступеня їх відкритості відповідно до динаміки розвитку цілей його створення i використання, а також обмежень психологопедагогічного, науково-технічного i ресурсного характеру, забезпечення безпеки життєдіяльності користувачів таких систем [22].

\section{4. ВИСНОВКИ ТА ПЕРСПЕКТИВИ ПОДАЛЬШИХ ДОСЛІДЖЕНЬ}

1. Наведене концептуальне бачення розвитку ІКТ та інструментів, що базуються на них, слід вважати програмним, оскільки фінансування одразу по всіх актуальних i майбутніх напрямах теоретичних i практичних досліджень ведеться у США на державному рівні за ключовими напрямами 3 метою екстенсивного застосування практично для всіх галузей, цивільних і воєнних задач. Результати виконання проектів (на початок 2015 р. вже опубліковані сотні статей і десятки монографій) визначать широкий спектр інвестицій у бізнес-проекти як інноваційні розробки для різних сфер діяльності людини: освіти, соціальних програм, виробництва, бізнесу, воєнної справи.

2. Аналіз тенденцій і отриманих поточних і кінцевих результатів дозволить українським ученим заощадити ресурси на дослідження, що можуть повторювати i дублювати результати виконання проектів Національного фонду науки США, а також використати ці результати як платформу для власних розробок, що випереджають світовий рівень.

3. Для системи освіти, можливо, найбільше значення з розглянутих напрямів буде мати робастний інтелект, який може суттєво вплинути на засоби і формування середовища навчання.

4. Окремої уваги потребує розуміння потенціалу людино-центричних (антропоцентричних) систем та інформаційно-психологічної безпеки користувача, у тому числі користувачів соціальних мереж.

\section{СПИСОК ВИКОРИСТАНИХ ДЖЕРЕЛ}

1. Тоффлер, Э. Шок будущего = Future Shock, 1970. - М. : АСТ, 2008. - 560 c.

2. Кремень В. Г. Людина перед викликом цивілізації: творчість, людина, освіта / В. Г. Кремень // Феномен інновацій: освіта, суспільство, культура / за ред. В. Г. Кременя. - К. : Педагогічна думка - 2008. - C. 9-48.

3. Daniel S. Papp and David Alberts. Preface: Technology and Change in Human Affairs. The Information Age: An Anthology on Its Impact and Consequences. Edited by David S. Alberts and Daniel S. Papp. CCRP Publication Series.1997. Pp. ii-viii.

4. Буров О. Ю. Людський капітал і ресурси в інтелектуальній економіці / О. Ю. Буров. // Питання інтелектуальної власності: зб. наук. праць. Випуск 11 / редкол. : О. П. Орлюк та ін.; НДІІВ. НАПрНУ. - 2013. - С. 4-11.

5. До суспільства знання: Всесвітня доповідь ЮНЕСКО. - ЮНЕСКО, 2005 р.- 444 с.

6. Биков В. Ю. Інноваційний розвиток засобів і технологій систем відкритої освіти / В. Ю.Биков //Сучасні інформаційні технології та інноваційні методики у підготовці фахівців: методологія, теорія, досвід, проблеми: Зб.наук. праць. - Випуск 29. Редкол.: І. А.Зязюн (голова) та ін.. - КиївВінниця : ТОВ фірма «Планер», 2012. - С. 32-40. 
7. Биков В. Ю., Лапінський В. В. Методологічні та методичні основи створення і використання електронних засобів навчального призначення // Комп’ютер у школі та сім’ї. - 2012. - №2. - С. 36.

8. Шишкіна М. П., Спірін О. М., Запорожченко, Ю. Г. Проблеми інформатизації освіти України в контексті розвитку досліджень оцінювання якості засобів ІКТ // Інформаційні технології і засоби навчання. - 2012. - \#1 (27). - Режим доступу до журналу : http://www.journal.iitta.gov.ua .

9. Спірін О. М. Критерії і показники якості інформаційно-комунікаційних технологій навчання / О. М. Спірін // Інформаційні технології і засоби навчання. - 2013. - №1 (33). - Режим доступу до журналу : http://journal.iitta.gov.ua.

10. Буров А. Ю. Ергономічні основи розробки систем прогнозування працездатності людиниоператора на основі психофізіологічних моделей діяльностіі : автореф. дис. ... доетора техн. наук: 05.01.04 / Харк. нац. академ. міськ. госп-ва. - Харків, 2007. - 40 с.

11. Буров О. Ю. Технології та інновації в діяльності людини ери інформації: проблеми інформації та технології / О. Ю. Буров // Інформаційні технології і засоби навчання. Електронне наукове фахове видання Online: 2076-8184. - 2015. - № 5 (49). - С. 16-25. - Режим доступу : http://journal.iitta.gov.ua/index.php/itlt/article/view/1274.

12. James N. Rosenau, Turbulence in World Politics: A Theory of Change and Continuity (Princeton: Princeton University Press, 1990).

13. Kleinberg Jon. "Analysis of large-scale social and information networks," Philosophical Transactions of the Royal Society A, v.371, 2013, p. ?. Jon Kleinberg. "Analysis of large-scale social and information networks," Philosophical Transactions of the Royal Society A, v.371, 2013, p. ?.

14. Flache, A; Macy, M. W. "Local Convergence and Global Diversity: From Interpersonal to Social Influence," JOURNAL OF CONFLICT RESOLUTION, v.55, 2011, p. 970.

15. Information and Intelligent Systems: Advancing Human-Centered Computing, Information Integration and Informatics, and Robust Intelligence. [Електронний ресурс]. - Режим доступу : http://www.nsf.gov/pubs/2006/nsf06572/nsf06572.htm\#toc.

16. Burov O. Virtual Life and Activity: New Challenges for Human Factors/Ergonomics. Symposium "Beyond Time and Space" STO-MP-HFM-231. STO NATO 2014, pp. 8-1..8-8.

17. Yamaguchi, T.; Sato, E.; Takama, Y. Intelligent space and human centered robotics. Industrial Electronics, IEEE Transactions. 2003. V.50, Is.5. $881-889$.

18. Information and Intelligent Systems: Advancing Human-Centered Computing, Information Integration and Informatics, and Robust Intelligence. [Електронний ресурс]. - Режим доступу http://www.nsf.gov/pubs/2006/nsf06572/nsf06572.htm\#toc.

19. Veltman H. Operator functional state assessment. Cognitive load / H. Veltman, G. Wilson, O. Burov // NATO Science Series RTO-TR-HFM-104.- Brussels, 2004.- P. 97 -112.

20. Mulder, L. J. M. et al. How to use cardiovascular state changes in adaptive automation / L. J. M. Mulder, A. Van Roon, H. Veldman, K. Laumann, A. Burov, L. Quispel, P.J. Hoogeboom. In: Hockey, G. R. J., Gaillard, A. W. K., Burov, O. (Eds.), Operator Functional State. The Assessment and Prediction of Human Performance Degradation in Complex Tasks. NATO Science Series. IOS Press, - Amsterdam, 2003. - Pp. 260-272.

21. Cyber-Human Systems (CHS) [online]. - Available from : http://www.nsf.gov/cise/iis/chs_pgm13.jsp.

22. Кузнецов В. О. Концепція освіти з напряму "Безпека життя і діяльності людини" / В. О. Кузнецов, В. В. Мухін, О. Ю. Буров, Л. А. Сидорчук, В. М. Заплатинський, С. А. Шкребець // Інформаційний вісник «Вища освіта». - К. Видавництво Науково-методичного центру вищої освіти МОНУ. - № 6 $-2001 .-$ C. $6-18$.

Матеріал надійшов до редакиії 08.12.2015 p

\section{ТЕХНОЛОГИИ И ИННОВАЦИИ В ДЕЯТЕЛЬНОСТИ ЧЕЛОВЕКА ЭРЫ ИНФОРМАЦИИ: ЧЕЛОВЕК И ИКТ}

\section{Буров Александр Юрьевич}

доктор технических наук, ведущий научный сотрудник отдела технологий открытой обучающей среды Институт информационных технологий и средств обучения НАПН Украины, г. Киев, Украина ayb@iitlt.gov.ua

Аннотация. В статье приводится краткий обзор проектов, начатых Национальным фондом науки США, которые касаются новых знаний по интеграции и совместном развитии 
социальных систем, имеют потенциал для трансформации науки/исследований, улучшения качества жизни и экономического процветания, а также должны обеспечить опережающее развитие информационно-комуникационных технологий для всех сфер деятельности человека: антропоцентрическая компьютеризация, интеграция информации и информатики, робастный интеллект, системы человек - киберпространство, а также двух перекрестных технических областей - взаимодействие людей и/или роботов, безопасность и защита информации.

Ключевые слова: информационно-коммуникационные технологии; интеллектуальные сети; антропоцентрические системы.

\title{
TECHNOLOGY AND INNOVATION IN HUMAN ACTIVITY OF THE INFORMATION AGE: HUMAN AND ICT
}

\author{
Oleksandr Yu. Burov \\ Dr.Sc. (Eng.), leading researcher of the Department of Technologies of Open Learning Environment \\ Institute of Information Technologies and Learning Tools of the NAES of Ukraine, Kyiv, Ukraine \\ ayb@iitlt.gov.ua
}

\begin{abstract}
In the article a brief overview of projects initiated by the U.S. National Science Foundation that related to new knowledge on integration and mutual development of social systems is proposed. The projects have a potential for transformation of science and researches, improvement of life quality and economy prosperity, as well as they should ensure outrunning development of information and communication technologies for all spheres of human activity: anthropocentric computerization, integration of information and informatics, robust intelligence, cyber-human systems, as well as two cross-technical areas - human and/or robots interaction, security and information protection.
\end{abstract}

Keywords: information and communication technologies; intelligent network; anthropocentric system.

\section{REFERENCES (TRANSLATED AND TRANSLITERATED)}

1. Toffler, A. Future Shock, 1970. - M.: ACT, 2008. - 560 c. (in Russian)

2. Kremen V. H. Human in face of the civilization challenge: creativity, human, education / V. H. Kremen // Fenomen innovatsii: osvita, suspilstvo, kultura / za red. V. H. Kremenia. - K. : Pedahohichna dumka 2008. - C. 9-48. (In Ukrainian)

3. Daniel S. Papp and David Alberts. Preface: Technology and Change in Human Affairs. The Information Age: An Anthology on Its Impact and Consequences. Edited by David S. Alberts and Daniel S. Papp. CCRP Publication Series.1997. Pp. ii-viii (in English).

4. Burov O. Yu. Human capital and resources in the intellectual economy / Oleksandr Yuriyovych Burov. // Pytannya intelektual'noyi vlasnosti: zb. nauk. prats'. Vypusk 11 / redkol. : O. P. Orlyuk ta in.; NDIIV. NAPrNU. - 2013. - S. 4-11. (in Ukrainian).

5. Towards a knowledge society: UNESCO World REport. - UNESCO, 2005 r. - 444 s. (in Ukrainian).

6. Bykov V. Yu. The innovative development tools and technologies for open education / V. Yu. Bykov //Suchasni informatsiyni tekhnolohiyi ta innovatsiyni metodyky u pidhotovtsi fakhivtsiv: metodolohiya, teoriya, dosvid, problemy: Zb.nauk. prats'. - Vypusk 29. Redkol.: I.A.Zyazyun (holova) ta in.. - KyyivVinnytsya: TOV firma «Planer», 2012. - S. 32- 40. (in Ukrainian).

7. Bykov V. Yu., Lapinskyi V.V. Methodological and methodical bases of creation and use of electronic means for educational purposes // Kompiuter u shkoli ta simi. - 2012. - №2. - C. 3-6. (in Ukrainian).

8. Shyshkina M. P. / Challenges of Informatization in Education of Ukraine in the context of study of the ICT quality evaluating [online] / M. P. Shyshkina, O. M. Spirin, Yu. H. Zaporozhchenko // Informatsiyni tekhnolohiyi i zasoby navchannya. - 2012. - №1 (27). - Available from : http://www.journal.iitta.gov.ua . (in Ukrainian).

9. Spirin O. M. Criteria and indicators of quality ICT training. Informatsiini tekhnolohii i zasoby navchannia. [online] / O. M. Spirin // Informatsiini tekhnolohii i zasoby navchannia. - 2013. - №1 (33). Available from: http://journal.iitta.gov.ua (in Ukrainian) 
10. Burov A. Yu. Ergonomic fundamentals of the systems' development for a human-operator capacity for work prediction on basis of psychophysiological models of activity: Avtoref. dys. ... d-ra tekhn. nauk: 05.01.04/ Khark. nats. akadem. mis'k. hosp-va.— Kharkiv, 2007.— 40 s. (in Ukrainian).

11. Burov O.Yu. Technology and innovation in human activity of the information age: information challenges and technologies [online] / O.Yu. Burov // Informatsiyni tekhnolohiyi i zasoby navchannya. 2015. - №5 (49). - Pp. 16-25. - Available from: //journal.iitta.gov.ua/index.php/itlt/article/view/1274. (in Ukrainian).

12. James N. Rosenau, Turbulence in World Politics: A Theory of Change and Continuity (Princeton: Princeton University Press, 1990). (in English).

13. Kleinberg Jon. "Analysis of large-scale social and information networks," Philosophical Transactions of the Royal Society A, v.371, 2013, p. ?. Jon Kleinberg. "Analysis of large-scale social and information networks," Philosophical Transactions of the Royal Society A, v.371, 2013, p. (in English).

14. Flache, A; Macy, M. W. "Local Convergence and Global Diversity: From Interpersonal to Social Influence," JOURNAL OF CONFLICT RESOLUTION, v.55, 2011, p. 970. (in English).

15. Information and Intelligent Systems: Advancing Human-Centered Computing, Information Integration and Informatics, and Robust Intelligence. [online]: - Available from: http://www.nsf.gov/pubs/2006/nsf06572/nsf06572.htm\#toc (in English).

16. Burov O. Virtual Life and Activity: New Challenges for Human Factors/Ergonomics. Symposium "Beyond Time and Space" STO-MP-HFM-231. STO NATO 2014, pp. 8-1...8-8. (in English).

17. Yamaguchi, T.; Sato, E.; Takama, Y. Intelligent space and human centered robotics. Industrial Electronics, IEEE Transactions. 2003. V.50, Is.5. 881-889. (in English).

18. Information and Intelligent Systems: Advancing Human-Centered Computing, Information Integration and Informatics, and Robust Intelligence. [online]. - Available from : http://www.nsf.gov/pubs/2006/nsf06572/nsf06572.htm\#toc. (in English).

19. Veltman H. Operator functional state assessment. Cognitive load / H. Veltman, G. Wilson, O. Burov // NATO Science Series RTO-TR-HFM-104. - Brussels, 2004.- P. 97-112. (in English).

20. Mulder, L. J. M. et al. How to use cardiovascular state changes in adaptive automation / L. J. M. Mulder, A. Van Roon, H. Veldman, K. Laumann, A. Burov, L. Quispel, P. J. Hoogeboom. In: Hockey, G. R. J., Gaillard, A. W. K., Burov, O. (Eds.), Operator Functional State. The Assessment and Prediction of Human Performance Degradation in Complex Tasks. NATO Science Series. IOS Press, Amsterdam, 2003. Pp. 260-272. (in English).

21. Cyber-Human Systems (CHS) [online]. - Available from: http://www.nsf.gov/cise/iis/chs_pgm13.jsp. (in English).

22. Kuznetsov V. O. Education concept in domain "Safety of human life and activity" / V. O. Kuznetsov, V. V. Mukhin, O. Yu. Burov, L. A. Sydorchuk, V. M. Zaplatyns'kyy, S. A. Shkrebets' // Informatsiynyy visnyk «Vyshcha osvita». - K. : Vydavnytstvo Naukovo-metodychnoho tsentru vyshchoyi osvity MONU, \# 6, 2001. - S. 6- 18. (in Ukrainian).

\section{(cc) BY-NC-SA}

This work is licensed under Creative Commons Attribution-NonCommercial-ShareAlike 4.0 International License. 